\title{
Postglacial Fire FrequenCy AND ITS RELATION TO LONG-TERM VEGETATIONAL and Climatic Changes in Yellowstone Park
}

\author{
CATHY WHITLOCK $\bullet$ DEPARTMENT OF GEOGRAPHY \\ UNIVERSITY OF OREGON $\bullet$ EUGENE
}

\section{$\checkmark \quad$ INTRODUCTION}

The paleoecologic record provides unique insights into the response of communities to environmental perturbations of different duration and intensity. Climate is a primary agent of environmental change and its long-term effect on the vegetation of the Yellowstone/Grand Teton region is revealed in a network of pollen records (Whitlock, 1993). Fire frequency is controlled by climate, and as climate changes so too does the importance of fire in shaping spatial patterns of vegetation. The prehistoric record of Yellowstone's Northern Range, for example, shows the response of vegetation to the absence of major fires in the last 150 years (Whitlock et al., 1991; Engstrom et al., 1991). In longer records spanning the last 14,000 years, periods of frequent fire are suggested by sediments containing high percentages of fire-adapted trees, including lodgepole pine and Douglas-fir, and high amounts of charcoal (Barnosky et al., 1987; Millspaugh and Whitlock, 1993; Whitlock, 1993).

The primary research objective has been to study the vegetational history of Yellowstone and its sensitivity to changes in climate and fire frequency. This information is necessary to understand better the relative effects of climate, natural disturbance, and human perturbation on the Yellowstone landscape. Fossil pollen and plant macrofossils from dated-lake sediment cores provide information on past vegetation and climate. The frequency of charcoal particles and other fire indicators in dated lake-sediment cores offer evidence of past fires.
The research has been divided into three parts:

1. A study of the depositional processes that incorporate charcoal into lake sediments. At regular time intervals, we are collecting surface sediments at different water depths from lakes with catchments that were burned in 1988 and from lakes with unburned catchments. From these surface samples, we are relating charcoal abundance to basin size, water depth, and fire proximity.

2. An analysis of the last ca. 800 years from lake-sediment cores. We are examining charcoal abundance, pollen composition, and paleomagnetic characteristics of the sediment at closely spaced intervals in meter-long cores in order to determine if the stratigraphic evidence of fire correlates well with the fire chronology based on dendrological studies (Romme, 1982; Romme and Despain, 1989).

3. An analysis of postglacial vegetational and fire history. We are analyzing the pollen, charcoal, and magnetic susceptibility record in longer cores collected in different vegetation types in the Park to reconstruct vegetational and fire history on longer time scales. Pollen records are now available from the Central Plateau, the Northern Range, the Absaroka region of Yellowstone, the Pinyon Peak Highlands, and Jackson Hole (Whitlock, 1993; Whitlock and Bartlein, 1993). This year a pollen record was analyzed from Loon Lake in the Bechler region. Postglacial charcoal studies underway are focusing on sites in different geovegetation settings (Despain, 1990). 


\section{$\checkmark \quad$ STUdY AREA}

Sites for the post-1988 charcoal study were selected to provide a representation of burn conditions in 1988 and vegetation types. Study lakes are generally small $\left(<0.5 \mathrm{~km}^{2}\right)$ and have minor or no inflowing streams. Five of the lakes lie in the 1988 burned region (Grizzly Lake, Cascade Lake, Duck Lake, Goose Lake, and Lake of the Woods). Three lakes lie outside the burned region (Wrangler Lake, Sylvan Lake, and Dryad Lake). Short cores have been analyzed from Dryad Lake, Duck Lake, Mallard Lake, Grizzly Lake, Cygnet Lake, and West Thumb of Yellowstone Lake (Fig. 1). Lakes and fens where long cores have been collected for pollen studies are also shown in Figure 1.

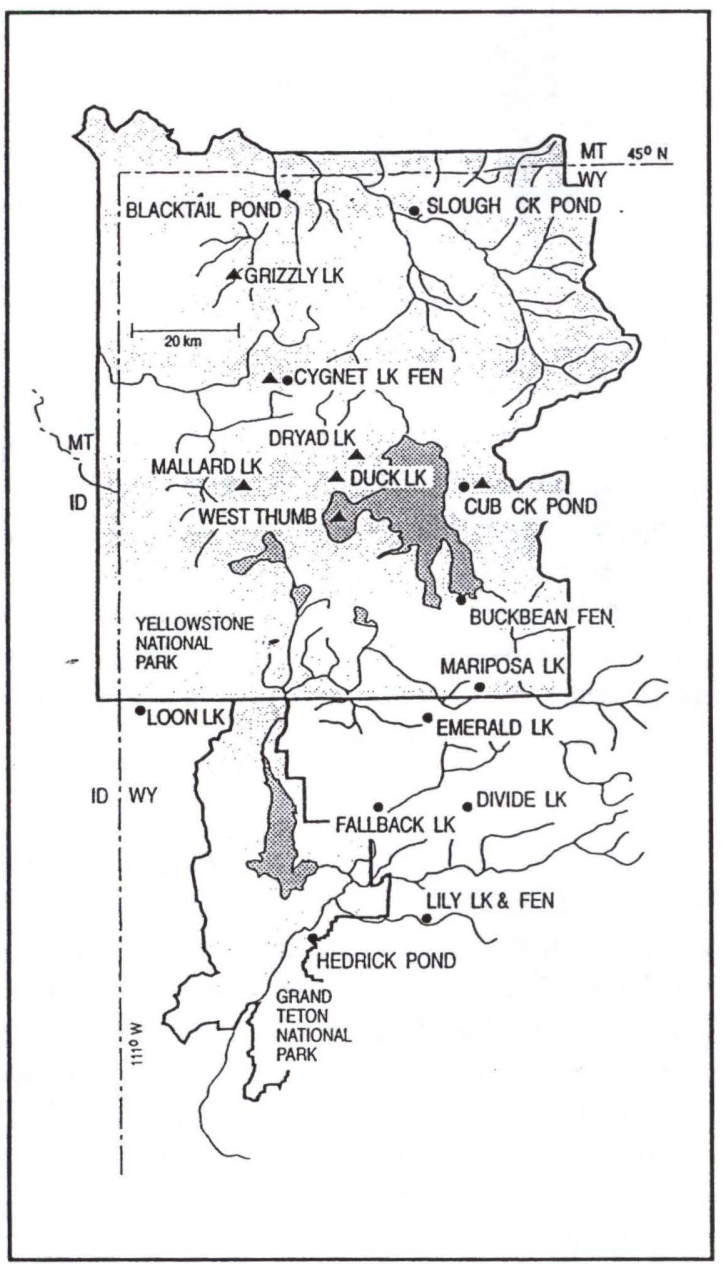

Figure 1. Location of study sites. Triangles indicate the locations of short-core sites for fire history research; circles are the location of fossil pollen sites.

\section{$\checkmark \quad$ METHODS}

FIELD WORK

Surface sediment was collected with a 5 $\mathrm{cm}$-diameter gravity sampler from an inflatable raft in July and August from the eight study lakes. Short cores were collected with a meter-long piston corer from a raft anchored in the deepest part of the lake. These cores were subsampled at $1 \mathrm{~cm}$ intervals in the field, and samples were stored in plastic bags. Long cores were recovered with a modified Livingstone sampler from an anchored platform in the deepest water or from the fen surface adjacent to the lake. Long cores were extruded and wrapped in the field.

\section{SHORT CORE AND SURFACE SAMPLE ANALYSIS}

Charcoal analysis was confined to macroscopic particles, using methods described by Millspaugh (1991). Surface sediment was sampled volumetrically, and the samples were desegregated in a dilute Calgon solution and gently sieved through $0.250 \mathrm{~mm}$ - and $0.125 \mathrm{~mm}$-mesh screens. The sediment fraction $<0.125 \mathrm{~mm}$ in size was saved for possible analysis in the future. Charcoal for each size fraction was tallied under a binocular microscope. Charcoal quantities were calculated as number of charcoal pieces $/ \mathrm{cm}^{2} / \mathrm{yr}$. Contiguous $1 \mathrm{~cm}$ samples taken from the short cores were analyzed in the same way as the surface samples.

Magnetic susceptibility was measured with a continuous-core magnetic susceptibility sensor. Measurements were taken every $\mathrm{cm}$ for short cores from Goose Lake, Mallard Lake, Dryad Lake, Duck Lake, Cygnet Lake, and Grizzly Lake. The lead-210 method was used to date sediments spanning the last 150-200 years in short cores. Lead-210 was measured through its granddaughter product $210 \mathrm{Po}$, with 208 Po added as an internal yield tracer. Dates and sedimentation rates were determined by Dr. William Schell (Department of Radiation Chemistry, University of Pittsburgh), using the constant rate of supply model (Appleby and Oldfield, 1978).

\section{LONG CORE ANALYSIS}

Long cores were sliced longitudinally, and each core segment was described. Samples of 0.5 $\mathrm{cm}^{3}$ size were taken at regular stratigraphic intervals 
for pollen and sediment analyses. One set of samples was used to determine the percentage of organic carbon and carbonate in the cores by measuring the weight-loss after ashing the samples at $550^{\circ}$ and $900^{\circ} \mathrm{C}$.

A second set of samples was taken for pollen analysis. All pollen samples were treated to standard laboratory procedures (Faegri et al. 1989, Cwynar et al. 1979). A tracer of Lycopodium pollen was added to each sample to calculate pollen concentration (grains $/ \mathrm{cm}^{3}$ ) and pollen accumulation rates (grains $/ \mathrm{cm}^{2} / \mathrm{yr}$ ). Preparations were mounted in silicon oil and examined at magnifications of 400 and $1000 x$.

Identification of fossil pollen was based on published atlases and the pollen reference collection at University of Oregon. Between 300 and 500 terrestrial pollen were identified and tallied per stratigraphic level. Pollen percentages were calculated for each sample. A denominator of total terrestrial pollen was used to calculate the percentage of each terrestrial pollen type. The sum of all pollen and spores (including aquatic taxa) was used to calculate the percentage of aquatic and fen taxa.

Radiocarbon dating of the sediment and tephrochronology were the main method for calculating the age of pollen stratigraphic and lithologic changes of the last 14,000 years. A tephra layer at Loon Lake was identified as Mazama ash, which was deposited from Mount Mazama in southwestern Oregon, ca. 6800 yr B.P. Two tephra layers at Cub Creek Pond were identified: an upper ash of reworked material, which may have been deposited during a local phreatic explosion (Whitlock, 1993; Sarna-Wojcicki, personal communication, 1989); and Glacier Peak ash (ca. 11,200-12,000 yr B.P.).

\section{$\checkmark \quad$ RESULTS AND DISCUSSION}

Charcoal particles between 0.125 and 0.250 $\mathrm{mm}$ seem to be a reliable indicator of a local catchment fire. Charcoal of this size range was found in the surface sediments of lakes in burned and unburned catchments during the first (March 1989) sampling (Fig. 2). This sampling was done in the interim between fire extinction in September 1988 and ice-off in May 1989, before secondary input of charcoal occurred. The March 1989 charcoal is attributed primarily to aerial fall-out during the fire. The increase of charcoal pieces in deep-water sediments since March 1989 is attributed to two sources. In burned catchments where riparian vegetation is poorly developed, charcoal has probably been introduced through erosion, although mass-wasting has probably declined in importance as slopes have become revegetated. Charcoal has also been introduced from the littoral zone, where it was initially deposited during the fires. Some of this material has subsequently moved to deep water as a result of sediment focusing.

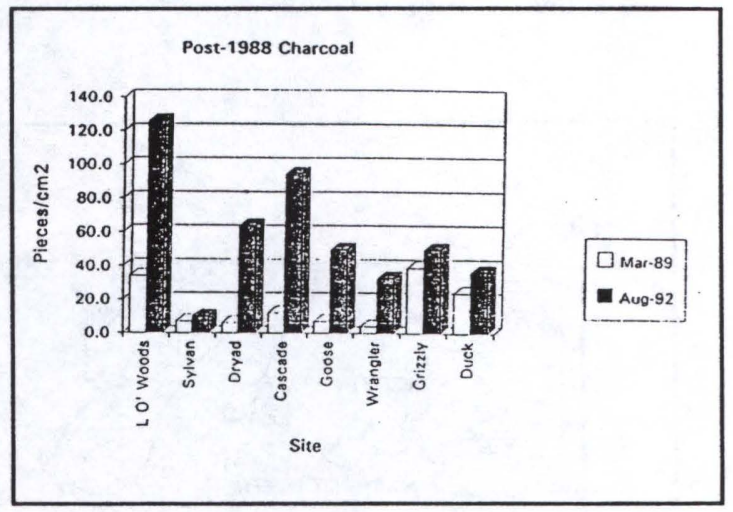

Figure 2. Graph showing charcoal abundance (pieces $/ \mathrm{cm}^{2}$ ) for post-1988 charcoal study. The graph compares deep-water sediments collected in March 1989 and August 1992. Sites are arragned by decreasing water depth: Duck Lake, $18 \mathrm{~m}$; Grizzly Lake, $11 \mathrm{~m}$; Wrangler Lake, $9.5 \mathrm{~m}$; Goose Lake, 9 m; Cascade Lake, $8.5 \mathrm{~m}$; Dryad Lake, $8 \mathrm{~m}$; Sylvan Lake, $7.5 \mathrm{~m}$; Lake of the Woods, $7.5 \mathrm{~m}$.

The magnitude of the charcoal increase between March 1989 and August 1992 appears to be partly related to water depth. Duck Lake $(18 \mathrm{~m}$ depth) and Grizzly Lake (11 m depth) are the deepest sites and both lie within burned catchments. They showed only modest increases in charcoal between 1989 and 1992, and the differences between the two sampling periods is not significant when a standard error of $20 \%$ is applied (Millspaugh, 1991). Thus, at these lakes, a 1988 fire event would not yet be recognized based on the charcoal content of the deep-water sediments. Apparently, more time is needed for sediment focusing to occur. A transect of samples from shallow to deep water suggests that 
charcoal is still being transported from shallow water, but not enough time has elapsed for it to reach deep water.

Relatively shallow lakes with burned catchments, such as Goose Lake ( $9 \mathrm{~m}$ deep), Cascade Lake (8.5 $\mathrm{m}$ deep), and Lake of the Woods (7.5 $\mathrm{m}$ deep) recorded significant increases in charcoal in the deep-water samples since March 1989 (Fig. 3). Further sampling in 1993 will determine whether this trend will continue.

Of the lakes with unburned catchments, Wrangler Lake (9.5 m deep) and Dryad Lake (8 m deep) showed significant increases in charcoal abundance from March 1989 to August 1992. The sites lie within $7 \mathrm{~km}$ of a burn, and both were located downwind of major fire plumes in 1988. The secondary charcoal probably came from the littoral zone and has been redeposited in deep water. Wrangler and Dryad lakes help define the limits of the charcoal method to identify a catchment fire. The charcoal "airshed" in 1988 at these sites was clearly larger than the watershed catchment. Sylvan Lake, the third site in an unburned catchment, has maintained relatively low charcoal amounts throughout the sampling period, although the number of pieces $/ \mathrm{cm}^{2}$ increased slightly between March 1989 and August 1992. Sylvan Lake did not lie downwind of a major fire storm, and apparently it received neglible amounts of airborne charcoal, and little has been added to the system through sediment focusing.

\section{FIRE HISTORY OF THE LAST ca. 800 YEARS}

Charcoal and magnetic susceptibility were compared in lead-210 dated short cores from Duck, Mallard, Dryad, and Grizzly and West Thumb of Yellowstone Lake. The records register widespread fires between ca. 1690-1750, a period that was also identified in the chronology developed by Romme and Despain (1989) from dendrologic records. Duck Lake records catchment fires on a 40-60 year frequency from ca. 1500 to ca. 1750 , but fires have been relatively rare since that time (Millspaugh, 1991). Duck, Mallard, and Dryad lakes record local fires between ca. 1560 and 1650 and between ca. 1690 and 1720 . The West Thumb record reveals three major fire episodes prior to 1988: ca. 1670-1700, ca. 1560, and ca. 1440. The periods from ca. 1400 to 1670 and ca. 1870 to 1988 are characterized by large infrequent fires. Prior to ca.
1400 and between 1670 to 1870 , fires were more frequent, but probably no event was as large as that of 1988. An absence of large fires from the late 17 th to the late 19th century may reflect cool wet conditions at the end of the Little Ice Age.

\section{VEGETATION, FIRE AND CLIMATE HISTTORY OF THE BECHLER REGION}

A new pollen record from Loon Lake provides information on the vegetational history of the Bechler region (Fig. 3). The record spans the last ca. 12,300 yr B.P. Prior to ca. 12,000 yr B.P., the pollen assemblage consists of high percentages of Artemisia, Picea, and Pinus (mostly $P$. albicaulis-type). Juniperus-type, Betula, Salix, Poaceae, and other herbs are also present in moderate amounts. The assemblage suggests a period of open spruce parkland, with birch and willow growing in wetter areas. The pollen data imply that upper treeline was at least $600 \mathrm{~m}$ lower and that the climate was ca. $5-6^{\circ} \mathrm{C}$ cooler than at present. The vegetation is similar to the spruce parkland that developed in the Pinyon Peak Highlands region between 14,000 and 11,200 yr B.P., except that whitebark pine (or limber pine) was present earlier in the Bechler region.

Between 12,000 and 10,000 yr B.P., the record features high percentages of Pinus albicaulis-type, and moderate percentages of Picea, Populus tremuloides-type, Artemisia, Poaceae, Cyperaceae, and other herbs. Pine and spruce were probably both present near the site during this period. The abundance of Populus pollen suggests that aspen was present in the Bechler region. The climate was warming, but conditions were cooler and moister than at present.

Percentages of Pinus contorta-type pollen increase at Loon Lake at ca. 10,000 yr B.P. Abies percentages also increase, although the low values do not suggest that it was a forest dominant. Picea, $P$. albicaulis-type, Juniperus-type, Populus, Poaceae, Cyperaceae, and Artemisia decline to low percentages after $10,000 \mathrm{yr}$ B.P. The expansion of lodgepole pine at the expense of spruce-whitebark (or limber) pine forest occurs throughout most of the Yellowstone/Grand Teton region. The establishment of lodgepole pine forest implies significant warming and probably a shift towards frequent fires. 


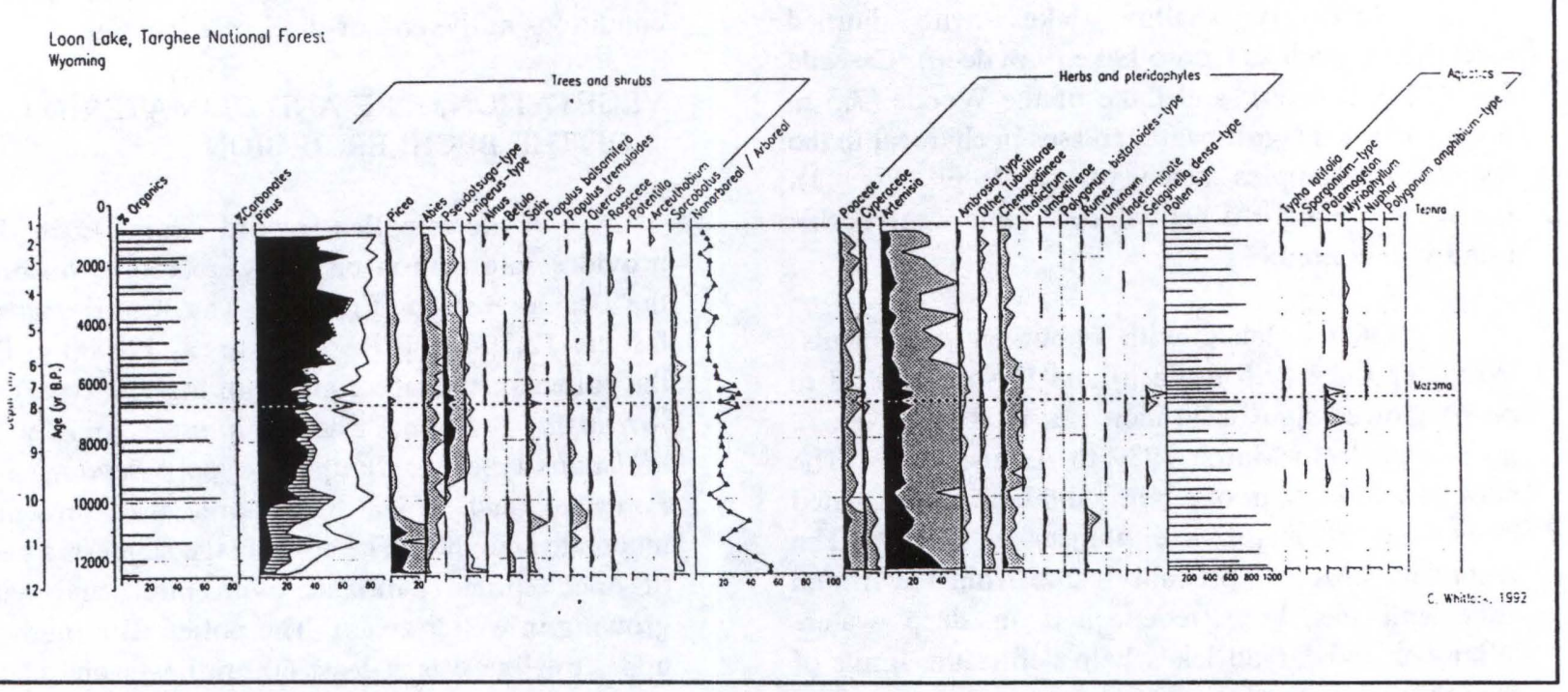

Figure 3. Pollen percentage diagram for Loon Lake, Wyoming (Lat. 4406 30, Long. 11057 00, elev. 1971 m).

Between 10,000 and 9500 yr B.P., continued warming allowed lodgepole pine to spread through the region, and it has been the dominant tree ever since. Percentages of Pseudotsuga and Populus indicate that Douglas-fir and aspen were present in the lodgepole pine forest between 9500 and $5000 \mathrm{yr}$ B.P. These taxa imply that warm arid conditions permitted xerothermic taxa to extend to higher elevations than at present. After $5000 \mathrm{yr}$ B.P., increases in Picea and Abies imply the onset of wetter cooler conditions.

Analysis of charcoal and magnetic susceptibility is currently underway in a long core from Cygnet Lake. The region surrounding Cygnet Lake is characterized by infertile rhyolitic soils that support lodgepole pine today. A long pollen record suggests that lodgepole pine forest has been maintained in rhyolite region for the last 10,000 years (Whitlock, 1993), probably as a result of the edaphic conditions. The persistence of this forest type throughout the Holocene enables an examination of climate-fire linkages in the absence of vegetation change.

Preliminary charcoal data suggest changes in fire frequency during the last 14,000 years. The record from the late Holocene reveals low background levels of charcoal punctuated by distinct peaks and suggests large fires occurred at 150 to $300-y r$ intervals. Consistently high levels of charcoal in the early Holocene record suggest fires were frequent. Distinct charcoal peaks occur at 30 to 100 -yr intervals from ca. 8400 to 9400 B.P. In the western U.S., this period is generally characterized by conditions that were warmer and drier than present. Changes in fire frequency in a region of unchanging vegetation suggests that fire regimes were directly linked to climate.

\section{- SUMMARY}

In an ongoing study of the fire history of Yellowstone Park, some preliminary conclusions can be drawn:

1. Most of the charcoal deposited in Yellowstone lakes from the 1988 fires was received as airborne fall-out. Two processes have been at work in the lakes since the 1988 fires. Charcoal has moved from shallow to deep water by sediment focusing. This process explains the increase in charcoal between March 1989 and August 1992 in 
unburned as well as burned sites. A second source of charcoal has come from eroded sediment moving into the lake from the burned watershed.

The greatest increase in charcoal has occurred in the deep-water sediments of relatively shallow lakes. The deep lakes have yet to show significant increases in charcoal levels. Sampling of charcoal distribution in the lakes will continue to be monitored in order to note changes in charcoal distribution with time. This information will be important when interpreting sedimentary charcoal in terms of past fire events.

2. Charcoal and magnetic susceptibility data from the short-core study indicate several local burns during the last 800 years. All sites burned between ca. 1690 and 1750. A record from West Thumb of Yellowstone Lake suggests large fires occurred in ca. 1690-1700, ca. 1560, and ca. 1440.

3. Fossil pollen data indicate that alpine meadow communities with birch and juniper were present between ca. 14,000 and $11,500 \mathrm{yr}$ B.P. following deglaciation. Spruce and whitebark (or limber) pine colonized the Bechler region as early as 12,000 yr B.P. By 10,500 yr B.P., the pollen record resembled modern spectra from subalpine forest. Between 10,000 and 9500 yr B.P. lodgepole pine developed throughout the region in response to further warming. Douglas-fir and aspen were present between 9500 and ca. 5000 yr B.P. in the Bechler region, suggesting the establishment of warmer and drier conditions. On the Central Plateau, charcoal evidence indicates more frequent fires during the early Holocene. Modern communities were established throughout the Yellowstone/Grand Teton region between 5000 and 4000 yr B.P.

\section{$\checkmark \quad$ Literature Cited}

Appleby, P.G. and Oldfield, F. 1978. The calculation of lead-210 dates assuming a constant rate of supply of unsupported $210 \mathrm{~Pb}$ to the sediment. Catena $5: 1-8$.

Barnosky, C.W., Anderson, P.M., and Bartlein, P.J. 1987. The northwestern U.S. during deglaciation; vegetational history and paleoclimatic implications. In: Ruddiman, W.F., and Wright, H.E., Jr., eds, North
America and Adjacent oceans during the last deglaciation: Boulder, Colorado, Geological Society of America. The Geology of North America, v. 3, pp. 289-321.

Cwynar, L.C., Burden, E., and McAndrews, J.H. 1979. An inexpensive method for concentrating pollen and spores from fine-grained sediments. Canadian Journal of Earth Sciences 16: 1115-1120.

Despain, D.G. 1990. Yellowstone vegetation; consequences of environment and history in a natural setting. Roberts Rinehart, New York.

Engstrom, D.R., Whitlock, C., Fritz, S.C., and Wright, H.E., Jr. 1991. Recent environmental changes inferred from the sediments of small lakes in Yellowstone's Northern Range. Journal of Paleolimnology 5: 139-174.

Faegri, K., Kaland, P.E., and Krzywinski, K. 1989. Textbook of pollen analysis. John Wiley and Sons, New York.

Millspaugh, S.H. 1991. A record of fire in the sediments of small lakes from Yellowstone National Park. M.S. thesis. Department of Geology and Planetary Science, University of Pittsburgh.

Millspaugh, S.H. and Whitlock, C. 1993. A long-term fire history of Yellowstone National Park reconstructed from lake sediment cores (abstract]. The ecological implications of fire in greater Yellowstone, Second Biennial Scientific Conference on the Greater Yellowstone Ecosystem, September 19-21. National Park Service, Yellowstone National Park.

Romme, W.H. 1982. Fire and landscape diversity in subalpine forests of Yellowstone National Park. Ecological Monographs 52: 199-221.

Romme, W.H., and Despain, D.G. 1989. Historical Perspective on the Yellowstone Fires of 1988. BioScience 39: 695-699. 
Whitlock, C. 1993. Postglacial vegetation and climate of Grand Teton and southern Yellowstone National Parks. Ecological Monographs 63: 173-178.

Whitlock, C. and Bartlein, P.J. 1993. Spatial variations of Holocene climatic change in the Yellowstone region. Quaternary Research 39: 231-238.
Whitlock, C., Fritz, S.C., and Engstrom, D.R. 1991. A prehistoric perspective on Yellowstone's Northern Range. In: R.B. Keiter and M.S. Boyce, editors. The Greater Yellowstone Ecosystem: Redefining America's Wilderness Heritage, pp. 289-305. Yale University Press. 